\title{
PREDICATIVE POSITION FOR SEVERAL $A$-WORDS AND ADVERBS
}

\author{
Ioan Beniamin POP
}

\begin{abstract}
Distinctions are sometimes made, at a more detailed level, in syntax, discriminating between predicative and non-predicative positions and functions of words. The present paper attempts to analyse how some a-words and adverbs behave in predicative position, as they can assume the specified place in several instances, even though only few of them can be freely used attributively. What is especially monitored in the present paper is the behaviour exhibited by adverbs, as they are notorious for avoiding such positions.
\end{abstract}

Key-words: linguistics, predicative position, a-words, a-adjectives, a-adverbs

\section{Introduction}

The term 'predicative' employed in this paper refers restrictively to the position a word assumes in a phrase or a sentence. We may speak about a predicative function, or 'used predicatively', when the word comes after verbs such as be, seem, feel, look, turn, etc., at times coined copulative or linking verbs.

The present paper studies how certain $a$-words behave in predicative positions, particularly adverbs beginning with $a$-, but also focusing on other adverbs. It is worth noticing, however, that certain $a$-words have always posed problems for grammarians in terms of their classification. Whereas some grammarians assigned them to the adjective class, others considered them as pertaining to the adverb class.

Only a relatively small number of adverbs, nonetheless, can be employed predicatively, due to the fact that they are notorious for avoiding predicative positions as well as attributive positions.

\section{Predicative position for $a$-adverbs}

Some place adverbs (aboard, there, upstairs, downstairs, around, near, etc and time adverbs (tomorrow, now, tonight, etc) can assume predicative positions in the sentence (cf. Quirk et al. 1985:408):

Their teacher was there.

\footnotetext{
* Lector dr., Departamentul de Filologie şi Studii Culturale, Facultatea de Litere Baia Mare, Universitatea Tehnică din Cluj-Napoca, str, Victoriei, nr. 76, Baia Mare, (pbeniamin@yahoo.com).
} 
Their teacher was downstairs.

Their teacher was around.

These adverbs are restricted in their predicative usage to occurring only in contexts qualified by $b e$. When a different copulative verb is employed, such as seem, they are considered ungrammatical:

The teacher was around

The teacher was abroad

* The teacher seemed around

* The teacher seemed abroad

There are indeed contexts in which adverbs are used predicatively with seem, by means of an artifice which also incorporates the copulative be as in: seem to be. All adverbs which allow predicative position can be used after this construction:

The teacher seemed to be around

The teacher seemed to be abroad.

With verbs like look, both $a$-adjectives and $a$-adverbs can be used, but the verb undergoes a semantic change and at the same time is subcategorized (a) as a copular verb, being s ynonymous with seem, and an intransitive verb in (b) respectively, where it is used with the approximate meaning 'to glance'.

a. We all looked asleep.

b. We all looked away.

Quirk et al. (1985:409) point out that adverbs and adjectives beginning with $a$ - differ in that the latter cannot be part of the predication after verbs of motion as they refer to temporary states, while adverbs used after such verbs denote motion, direction:

$\begin{array}{ll}\text { She went aboard } & \text { [adverbs] } \\ \text { She went abroad } & \text { [adverbs] } \\ \text { She went around } & \text { [adverbs] } \\ \text { She went } \text { away } & \text { [adverbs] } \\ \text { *She went afraid } & \text { [adjectives] } \\ \text { *She went } \text { alert } & \text { [adjectives] } \\ \text { *She went } \text { asleep } & \text { [adjectives] } \\ \text { *She went } \text { awake } & \text { [adjectives] }\end{array}$

There are, however, instances when such examples with $a$-adjectives can be interpreted as acceptable, on condition that the adjectives receive a different interpretation: they are no longer part of the predication but function as supplementive adjective clauses. Supplementive adjective clauses are instances in which an adjective can function as the head of an adjective phrase realizing the clause or as the sole realization of a verbless clause (cf. Quirk et al. 1985:424). Generally, they are related both to the predication and the subject:

(Quite) excited, his wife answered the phone. 
The sentence

He went afraid

might be accepted by means of reinterpreting it into

He was afraid as he went.

Ştefănescu (1978:307) considers some criteria in order to differentiate between adverbs and adjectives such as the ones above. She analyses their capability of assuming predicative and attributive positions, as well as of accepting modification by means of very, or comparison. Abroad, around, away unhesitatingly stand out as adverbs.

\section{Predicative position for other types of adverbs}

Adverbs can sometimes function with verbs normally serving as copulas, even if adjectives qualify for this position. In such cases, the verb is less empty of contents:

It is rare to shake hands with the president. [adjective]

It must be rarely that the English exile. [adverb]

How could it be otherwise? [adverb]

She actually feels tired. [adverb]

This is justifiable as she feels deeply about him. [adverb]

The verb be, when in combination with an adverb, seems to retain a value approaching that of 'happen'. In such expression as it is rarely that ...., or it is seldom ..., the adverbial form is usual. A different explanation alongside the change in value for be can be formulated in terms of modification. It appears that in the sentence

It must be rarely that the English exile

the adverb rarely was in the deep structure either pre- or post- modifying the verb exile - the English (rarely) exile (rarely)- and by means of different transformations, the adverb ends in the predicative position following the verb $b e$.

Verbs of perception such as smell, sound, feel, look do not normally take adverbs but rather have an adjective phrase as complement. Nicolescu (1977: 309) notices that despite the recommendation made by Quirk et al. (1980:239) that speakers use after 'recepient' sound and look adjective forms, the tendency goes against the norm when analyzing some examples in the literature of press:

"For its age the recording sounds astonishingly well to make this a keenly competitive version even today.

The Mephisto Waltz we have had before, otherwise coupled, and it still sounds well."

Words which may naturally describe the subject are generally found as adjectives while words expressing a person's reaction usually occur as adverbs:

The soup smells nice/ sweet. [adjective] 
The fish smells abominably/ unpleasantly. [adverb]

It seems that in the former example, smell has the value of 'is' whereas the meaning implied in the latter is 'emits smell'. The interpretation does not hold as a rule. Countless examples exist showing that there are uncertainties whether the adverbial value is accepted or not.

The flowers smell sweet/?sweetly.

The adverb is perceived as grammatical (in fact it is the adjective which triggers ungrammaticality) in sentences such as:

I can definitely say it smells *strong/strongly of fish.

Adverbs used in such contexts are felt to denote intensity of feelings. It is evident that there are prescriptive objections to the adverb form when comparing the adjective good and the adverb well.

The flowers smell good/*well.

The adverb well is felt sometimes to be acceptable, even though quite rare, after taste. Other adverb forms are less common.

The soup tastes good/ well.

The soup tastes marvelous/ *marvelously.

Roberts (1988:18) suggests a simple test in determining whether a word such as well behaves adverbially or adjectivally, and proposes to replace it with a true adverb, namely beautifully. If it is accepted in the same position, then well in similar sentences is an adverb. The difference, however, is not so clear cut, as is obvious in the following situation. Good and well can function in the same context after look, where well is no longer felt to be questionable but desirable. The distinction between well and good in such contexts is necessary in terms of discriminating between their semantic value. Caution is to be used here as the two values do not correspond to the different word-class of adverb and adjective respectively. Both good and well function as adjectives in the examples below:

Your girl looks good.

Your girl looks well.

The adjective good brings about the implication of 'appearance' while the adjective well refers to 'health'. Partridge (1994:6) makes the following recommendation:

"Use an adjective when the verb refers to the subject of the sentence, in which case it could be replaced by the verb to be, as in

The market closed steady. (It closed and it was steady)

or

The cat looked hungry. (It seemed to be hungry)

Use an adverb when the verb refers to the activity, as in

The market rose steadily

The cat looked hungrily at the fish."

There are, however, instances when adverbs are used with such verbs as fell and smell, in order to express intensity of feelings, as already 
mentioned. In some contexts, different semantic implications are involved, when either the adjective or the adverb is used:

a. The whole group felt bad (today).

b. The whole group felt bad/badly about it.

In (a), only the adjective form is possible, as the meaning implied is that of 'health'. In the latter example (b), the different semantic implication is triggered by the use of the prepositional phrase which no longer allows the interpretation of the adjective in terms of 'state of health', but rather attitude or (intensity of) feelings 'guilty' or 'uneasy'. The adjective form is more frequently used by speakers than the adverbial one.

Similar distinctions appear when other adverbs and counterpart adjectives are employed, as in:

a. We felt strong.

b. We felt strong/strongly about it.

Whereas the intensifying value of the adverb in (b) is evident, the adjective in (a) is connected with the physical sense of 'strength', projecting upon the subject the assigned characteristic - we were strong.

In the above pairs, slightly different contexts were provided in order to discriminate between the adjectival and adverbial usage and their different semantic implications. The adverb keenly and the adjective keen can, nonetheless, function in identical sentences in terms of constituent elements, with corresponding change in meaning (cf. Quirk et al. 1980:239):

a. The whole group felt keen about it.

b. The whole group felt keenly about it.

The value of feel in (a) can be reduced to the meaning of 'be' and thus trigger in the adjective the sense 'enthusiastic'. The adverb in (b) preserves its intensifying value on the verb feel.

Note that, in general, to characterize how something looks or sounds, it does not make a big difference whether we use an adverb or an adjective. Thus the following two sentences basically convey the same meaning:

a. The moon shines bright

b. The moon shines brightly

The only obvious difference lies in the fact that the quality of brightness conveyed by the adjective in (a) refers to the moon itself, while in (b) the brightness is associated to the way it shines. This line of thinking does not apply in a different situation, involving, for example, things which do not fall under the sphere of influence rendered by the semantic implication of the adjective bright. In other words, it is impossible for a thing which is not bright to shine brightly. Therefore, this difference in expression does not correspond to a difference in meaning. It would be quite different to say:

? The wood was burning bright. 
Bright is at least questionable here, if not ungrammatical, as it is not the wood, but the flame [burning], that is bright. Normally, only brightly qualifies here.

It is easy to represent the above facts in terms of transformational grammar. The sentence The moon shines bright would have underlying it such sentences as

The moon shines.

The moon is bright.

On the other hand, the sentence The moon shines brightly would have underlying it such sentences as

a. The moon shines.

b. THIS is bright.

The difference is even more obvious when taking the insert (a) and subjecting it to the gerundial transformation and then inserting it into (b), which results in:

The moon's shining is bright.

The sentence The wood was burning brightly has the following derivation:

The wood was burning.

THIS was bright.

By applying the same transformation as above, the resulting sentence is

The wood's burning was bright,

similar to The moon's shining is bright, which contains in its final surface structure the adverb form of the word bright.

By employing this, it is possible to show that The wood was burning bright is ungrammatical. The underlying sentences would be:

The wood was burning.

*The wood was bright.

As one of the underlying sentences cannot exist due to selectional restrictions (brightness is not normally associated with nouns such as wood), the resulting sentence is also considered ungrammatical.

\section{Conclusions}

Although predicative positions are rather more appropriate for the word class of adjectives, adverbs can, at times, function with verbs which fulfill the grammatical role of copulas. Even though the most frequently encountered combination is the one retaining the verb be as copula, there are, however, instances, when adverbs are used with such verbs as feel and smell, for instance.

At times, it seems difficult to discriminate between $a$-adverbs and $a$ adjectives. Nevertheless, when analyzing the fact that they may or may not assume predicative and attributive positions, as well as that they accept 
modification in the degree of comparison, it becomes evident that they behave as adverbs.

\section{Bibliography}

Aarts, Bas. 1997. English Syntax and Argumentation. New York: St. Martin's Press.

Alexiadou, Artemis. 1997. Adverb Placement. A Case Study in Antisymmetric Syntax. Philadelphia: John Benjamins Publishing Company.

Bonami, Olivier and Danièle Godard. 2008. 'Lexical semantics and pragmatics of evaluative adverbs' in Adjectives and Adverbs: Syntax, Semantics, and Discourse. McNally, Louise and Christopher Kenney (eds.) Oxford: Oxford University Press, p. $274-304$.

Delfitto, Denis. 2006. 'Adverb Classes and Adverb Placement' in The Blackwell Companion to Syntax. Volume I. Martin Everaert and Henk van Riemsdijk (eds.). Victoria: Blackwell Publishing, p. 83-120.

Doetjes, Jenny. 2008. 'Adjectives and degree modification' in Adjectives and Adverbs: Syntax, Semantics, and Discourse. McNally, Louise and Christopher Kenney (eds.) Oxford: Oxford University Press, p. 123 - 155.

Haumann, Dagmar. 2007. Adverb Licensing and Clause Structure in English. Philadelphia: John Benjamins Publishing Company.

Katz, Graham. 2008. 'Manner modification of state verbs' in Adjectives and Adverbs: Syntax, Semantics, and Discourse. McNally, Louise and Christopher Kenney (eds.) Oxford: Oxford University Press, p. 220 - 248.

Lorenz, Gunter. 2002. 'Really worthwhile or not really significant? A corpus-based approach to the delexicalazation and grammaticalization of intensifiers in Modern English' in Typological Studies in Language 49: New Reflections on Grammaticalization. I. Wischer and G. Diewald (eds.). Amsterdam and Philadelphia: John Benjamins Publishing Company, p 143 - 162.

Nicolescu, Adrian. 1977. Tendinţe în engleza britanică contemporană. Bucureşti: Tipografia Universităţii din Bucureşti.

Partridge, Eric. 1994 (1942). Usage and Abusage. London: Penguin Books.

Piñón, Christopher. 2005. 'Adverbs of Completion in an Event Semantics' in Studies in Theoretical Psycholinguistics: Perspectives on Aspect vol. 32. Henk Verkuyl, Henriette de Swart and Angeliek van Hout (eds.). Amsterdam: Springer Netherlands p. 149 - 166.

Pop, Ioan Beniamin. 2016. 'Initial position of adverbs in the sentence and their relative freedom of movement' in Annales Universitatis Apulensis. Series Philologica, Nr. 17, tom 2 / 2016 ISSN 1582-5523, indexat EBSCO, p. 349356

Quirk, Randolph, Sydney Greenbaum, Geoffrey Leech, Jan Svartvik. 1980 (1972). A Grammar of Contemporary English. Essex: Longman Group UK Limited. 
Quirk, Randolf, Sidney Greenbaum, Geoffrey Leech, Jan Svarvik. 1985. A Comprehensive Grammar of the English Language. London and New York: Longman Group UK Limited.

Roberts, Philip Davies. 1988 (1987). Plain English: A User's Guide. London: Penguin Books.

Svenonius, Peter. 2001. 'Subject Positions and the Placement of Adverbials' in Subjects, Expletives, and the EPP. Peter Svenonius (ed.). New York: Oxford University Press.

Svorou, Soteria. 2002. 'Semantic constraints in the grammaticalization of locative constructions' in Typological Studies in Language 49: New Reflections on Grammaticalization. I. Wischer and G. Diewald (eds.). Amsterdam and Philadelphia: John Benjamins Publishing Company, p 121 - 142.

Ştefănescu, Ioana. 1978. Lectures in English Morphology. Bucureşti: Tipografia Universităţii din Bucureşti.

Wyner, Adam Zachary. 2008. 'Towards flexible types with constraints for manner and factive adverbs' in Adjectives and Adverbs: Syntax, Semantics, and Discourse. McNally, Louise and Christopher Kenney (eds.) Oxford: Oxford University Press, p. $249-273$. 